\title{
A POLÍTICA MIGRATÓRIA BRASILEIRA PARA REFUGIADOS E A IMIGRAÇÃO HAITIANA
}

\section{A MIGRATION POLICY BRAZILIAN FOR REFUGEE AND IMMIGRATION HAITLAN}

\author{
César Augusto S. da Silva ${ }^{1}$ \\ Thays de Mello Moraes ${ }^{1}$
}

Recebido em: 25/07/ 2016 Aceito em: 22/12/2016

cesarsilva@ufgd.edu.br thays-moraes@hotmail.com

\begin{abstract}
Resumo: O foco deste trabalho é a crescente imigração haitiana em direção ao Brasil, tendo como objetivo associar essa grande emigração à violação maciça de direitos humanos e à incapacidade do Estado de garantir segurança e estabilidade à sua população, e não somente aos fatores econômicos e ambientais como analisa o Estado brasileiro para Ihes negar a condição de refugiados. É analisada e contestada neste texto a medida adotada pelas autoridades brasileiras de conceder visto humanitário aos haitianos, de forma provisória, quando parece evidente que a violação maciça de direitos humanos no país é um dos critérios da Declaração de Cartagena de 1984 e da própria lei brasileira. Conclui-se a respeito de como o país se posiciona perante a emigração haitiana, levantando hipóteses de política externa do porque não o faz no âmbito da compreensão da totalidade dos direitos humanos internacionais.
\end{abstract}

Palavras-chave: Imigração haitiana. Refugiados. Política Externa. Direitos Humanos. Migração Internacional.

\begin{abstract}
The focus of this work is the growing Haitian immigration into Brazil, aiming to associate this great emigration to the massive violation of human rights and the state's inability to guarantee security and stability to its people, not economic and environmental factors such analyzes the Brazilian state to deny them refugee status. It is analysed and challenged in this text the measure adopted by Brazilian authorities to grant visa humanitarian Haitians, provisionally, when it seems evident that the massive violation of human rights in the country is one of the Cartagena Declaration criteria and own Brazilian law. It follows as to how the country stands before the Haitian emigration, raising chances of foreign policy because they do not do it within the understanding of all international human rights.
\end{abstract}

Keywords: Haitian immigration. Refugees. Foreign Policy. Human Rights. International Migration

\section{INTRODUÇÃO}

O Haiti é um pequeno país montanhoso de 27.500 quilômetros quadrados, localizado na bacia do Caribe. Apesar de ter sido a primeira república negra na história das Américas a declarar sua independência após uma revolta escravista, o país carrega consigo um histórico político e econômico pesaroso devido ao excessivo uso da violência pelos governos ditatoriais, às dificuldades de afirmar-se Estado e de construir uma identidade nacional.

Desde sua independência, o Haiti passou por crises políticas e econômicas que foram tornando instável o cenário interno do país. Ele passou por diversos golpes de Estado e teve sucessivos governos opressores e sanguinários, passando a ser o centro da agenda da comunidade internacional que, preocupada com a violência generalizada e a violação dos direitos humanos, passou a investir em intervenções para a redemocratização do país (MAJISTATIC, 2014).

\footnotetext{
${ }^{1}$ Universidade Federal da Grande Dourados - UFGD - Dourados - Mato Grosso do Sul - Brasil
} 
Somado a isso, a situação econômica do Haiti sempre esteve em decadência pela incompetência de suas elites governantes, contribuindo para a miséria do país ao longo do tempo (ZOLBERG, SURHKE e AGUAYO, 1989. p. 182). Diante desse caos interno, os fluxos de emigração começaram a crescer ao longo dos anos como a única maneira encontrada pela população de fugir da violência e de garantir sua sobrevivência.

Em meio a esse contexto político, o Haiti também sofreu diversos desastres ambientais que contribuíram para o subdesenvolvimento do país, e os fluxos aumentaram particularmente após o terremoto de 2010. Nesse período, o Brasil foi um destino redescoberto pelos haitianos, que entraram em um número relativamente alto no país, dividindo opiniões na sociedade, entre autoridades do governo e as instituições migratórias diante do visto complementar de caráter humanitário que o Brasil concedeu à população (TÉLÉMAQUE, 2012).

O objetivo do presente trabalho é compreender de que forma essa medida protetora está em conformidade com a política externa do Brasil, que desde o final do governo de Fernando Henrique Cardoso (1994-2002) e principalmente nos governos de Luis Inácio Lula da Silva (2003-2010) têm adotado uma postura de comprometimento com os assuntos humanitários, ratificando e criando as mais modernas legislações e colaborando financeiramente com os organismos internacionais. Isso porque o governo brasileiro tem visado obter prestígio internacional e um assento permanente no Conselho de Segurança da ONU.

Nesse sentido, o país incorporou à sua lei para refugiados o amplo reconhecimento como causa para o refúgio, a violação maciça dos direitos humanos, contido na Declaração de Cartagena de 1984. Entretanto, o governo brasileiro interpretou de forma restritiva sua própria legislação quando passou a negar solicitações de refúgio dos haitianos, levando-nos a questionar os critérios do processo decisório do CONARE (Comitê Nacional para Refugiados - vinculado à Secretaria Nacional de Justiça - ligado ao Ministério da Justiça).

Analisando o contexto histórico e político do Haiti, percebemos que esses fatores exógenos, implícitos na imigração haitiana, parece não serem levados em consideração nas decisões governamentais brasileiras. Dessa maneira, optamos por avaliar esse processo decisório sob a ótica da política externa brasileira para compreender de que forma essa decisão se torna estratégica e conveniente para o atual cenário do país. Afinal, o Brasil lidera uma missão de paz para a estabilização do Haiti há mais de dez anos, o que se leva a questionar a efetividade da missão, considerando que os fluxos emigratórios só aumentaram ao decorrer desses anos.

Consideramos importante o tema, pois a decisão do governo brasileiro em indeferir os pedidos de refúgio dos haitianos, encaminhando-os diretamente para o CNIG (Conselho Nacional de Imigração, ligado ao Ministério do Trabalho - que Ihes concedem o visto humanitário), parece ferir diretamente o direito dos haitianos de solicitarem refúgio, garantido pela própria legislação brasileira. Por isso a necessidade de se discutir em que dimensão a prática do governo nacional está de acordo com seus discursos em prol dos direitos humanos e dos assuntos humanitários. Ademais, também é preciso evidenciar de que forma o governo brasileiro e as entidades migratórias estão realmente preparadas para acolher refugiados no país.

Revista do Direito [ISSN 1982-9957]. Santa Cruz do Sul, v. 3, n. 50, p. 98-117, set./dez. 2016. https://online.unisc.br/seer/index.php/direito/index 
A metodologia aplicada é uma pesquisa qualitativa mediante levantamento bibliográfico nacional e internacional no âmbito da ciência política, direito e relações internacionais sobre o histórico político e econômico mais recente do Haiti. Além disso, é também feita uma análise interpretativa dos instrumentos legais de proteção aos refugiados, nacionais e regionais, a partir do ponto de vista de Hedley Bull (2002).

O texto tratará das prioridades da política externa brasileira, detalhando o comprometimento do país com as questões humanitárias e de direitos humanos. E também sobre a nova rota dos haitianos em direção ao Brasil, e de que forma o país recebe estes imigrantes no que tange ao seu acolhimento e inserção social.

Na última parte analisamos o posicionamento brasileiro em relação à solicitação de refúgio dos haitianos. O objetivo aqui é, portanto, entender de que forma a preocupação com a imagem do país perante a comunidade internacional interferiu para a negação do reconhecimento por parte do governo brasileiro de que os haitianos estariam em condições de serem acolhidos como refugiados.

Também levantamos a problemática da fragmentação das entidades migratórias brasileiras que atendem os imigrantes recém-chegados, que por vezes as tornam ineficazes. A lei para refugiados que o Brasil estabeleceu, com critérios da Declaração de Cartagena de 1984 sobre violação de direitos humanos, garantiria aos haitianos o direito ao refúgio, porém a interpretação restritiva da legislação levanta um questionamento sobre o processo decisório do CONARE e a conexão com a política externa brasileira.

\section{POLÍTICA EXTERNA BRASILEIRA E A IMIGRAÇÃO HAITIANA PARA O BRASIL}

A imigração haitiana para o Brasil teve grande repercussão na imprensa brasileira a partir de 2010. Devido ao pior terremoto do país, muitos haitianos redescobriram o Brasil como rota alternativa para migração, e o fluxo foi relativamente intenso. De fato, o país já havia sido uma alternativa para os haitianos desde 2004, e isso se deve à reorientação da política externa nacional para alcançar liderança regional nos assuntos humanitários e a uma determinada proximidade Brasil-Haiti.

Para Pinheiro e Milani (2012, p. 45) o Brasil passou a integrar os direitos humanos à sua plataforma de política externa desde 1977, todavia, o governo passou a respeitar as regras do regime multilateral de direitos humanos após a promulgação da Carta Magna de 1988. Conforme estes analistas, é estabelecido no artigo $4^{\circ}$ (inciso II) da Constituição que os direitos humanos devem ser prioridade nas relações internacionais do Brasil. Ou seja, constata-se que os sucessivos governos brasileiros passam a ter um comprometimento bastante sólido com os direitos humanos, sendo o país em desenvolvimento que mais ratifica convenções e tratados internacionais nesse campo.

Desde o final do governo de Fernando Henrique Cardoso (FHC) e principalmente nos mandatos de Luís Inácio Lula da Silva (Lula), o Brasil tem colocado ênfase nas questões humanitárias e priorizado a segurança internacional em sua agenda de política externa. Nesse contexto, Cervo e Bueno (2008) reafirmam que a política externa do Brasil passou a desempenhar um importante papel no campo da segurança. O país associou-se aos países do Cone Sul e comprometeu-se a levar a paz, desenvolvimento e redemocratização ao Haiti através da Missão de 
paz da ONU para a estabilização do Haiti (MINUSTAH). Os autores destacam a MINUSTAH como o mais importante envolvimento em Missões de Paz da ONU desde 1946.

Fernando Henrique Cardoso em discurso na Assembleia Geral da $\mathrm{ONU}^{2}$ ao final de seu mandato declarou que as portas do Brasil estavam abertas para integrar os refugiados no país. O expresidente ainda chamou atenção para a necessidade da construção de uma ordem internacional mais justa e solidária e iniciou uma discussão acerca da quantidade dos membros permanentes do Conselho de Segurança da ONU, demonstrando o forte desejo de obter um assento para o Brasil:

"(...) como todos aqueles que pregam a democratização das relações internacionais, o Brasil reclama a ampliação do Conselho de Segurança e considera ato de bom senso a inclusão, na categoria de membros permanentes, daqueles países em desenvolvimento com credenciais para exercer as responsabilidades que a eles impõe o mundo de hoje. (...)" (Fernando Henrique Cardoso, 2001).

Mostrando alinhamento a política externa de FHC, em 2004, Lula assina a Declaração e Plano de Ação do México para fortalecer a Proteção Internacional dos Refugiados na América Latina. ${ }^{3}$ Segundo o $\mathrm{ACNUR}^{4}$, o plano teve a adesão de 20 países e estabeleceu uma série de medidas para encontrar soluções duradouras para os refugiados da região. Dentre vários planos de ação o documento reafirmou: o compromisso dos assinantes com as pessoas que tem direito à proteção internacional na América Latina; a prioridade do humanismo e solidariedade na orientação das políticas de Estado a respeito de refugiados na América Latina e o direito fundamental da pessoa de buscar e receber asilo.

O plano de ação em destaque foi o Programa Regional de Reassentamento Solidário. Um programa voltado para os países da América Latina que se comprometem a realocar refugiados a um terceiro país. Isso acontece porque muitas vezes o refugiado não se adapta ao país que solicitou refúgio, ou porque esse país não pode Ihe garantir a proteção que buscava. Andrade e Marcolini (2002) sublinham que o governo brasileiro aderiu ao programa de reassentamento em 1999, conduzido por razões humanitárias. Conforme Pinheiro e Milani (2012), em 2006, o Brasil é o $12^{\circ}$ país que mais reassentou refugiados, principalmente os colombianos e palestinos. De acordo com Silva (2015, p.235), a adesão brasileira a essa política de reassentamento é a busca pela vanguarda dos temas humanitários em termos regionais, aumentando sua presença internacional. Isso porque apenas 16 países do mundo eram comprometidos com a causa naquele momento.

Ainda em 2004, o presidente Lula organizou o Jogo da Paz: levou os jogadores da seleção brasileira de futebol para o Haiti e promoveu, com o aval das Nações Unidas, um jogo entre as delegações do Brasil e Haiti, em um claro objetivo de aumentar seu capital político e ganhar

\footnotetext{
${ }^{2}$ Disponível em:<http://www.funag.gov.br/biblioteca/dmdocuments/Discursos_fhc.pdf $>$ Acesso em $15 / 02 / 2016$ às $19 h 00$.

${ }^{3}$ Disponível em:

$<$ http://www.acnur.org/t3/fileadmin/Documentos/portugues/BD_Legal/Instrumentos_Internacionais/Declarac ao_e_Plano_de_Acao_do_Mexico.pdf?view=1> Acesso em 25/02/2016 às $15 \mathrm{~h} 00$

${ }^{4}$ Disponível em: $<$

http://www.acnur.org/t3/fileadmin/Documentos/portugues/BD_Legal/Instrumentos_Internacionais/Declaraca o_e_Plano_de_Acao_do_Mexico.pdf?view=1> Acesso em 25/02/2016 às $16 \mathrm{h00}$.
} 
visibilidade internacional. Os brasileiros foram recebidos muito carinhosamente pelos haitianos que colocaram camisetas do Brasil e seguiram em festa a seleção que desfilava pelas ruas de Porto Príncipe em tanques da $\mathrm{ONU}^{5}$, numa demonstração de acolhimento e admiração pelo país que liderava a Missão de Paz.

O Jogo da Paz teve um simbolismo muito incisivo para a diplomacia brasileira. Não foi a primeira vez na história que o esporte foi utilizado como instrumento político para aproximar as relações bilaterais de dois países. Exemplo disso foi a série de jogos de tênis de mesa entre EUA e China que aconteceu no ano de 1971, no contexto da Guerra Fria. Após os jogos, os EUA suspenderam o embargo econômico de vinte anos contra a China, com o objetivo de dividir o mundo socialista da época. Já no contexto brasileiro, esse recurso diplomático também foi uma estratégia de propaganda do governo: o que Silva (2004) denomina de "marketing político".

Afinal, o futebol é uma prática esportiva que identifica o Brasil, além de conferir certo prestígio internacional ao país (ainda mais em 2004, quando o Brasil era o atual campeão mundial) o jogo representou o marco inicial da atuação da MINUSTAH e, contribuiu mais à frente para uma maior aceitação e simpatia dos haitianos pela intervenção brasileira. Desde então, o Haiti passou a ser um dos principais temas humanitários da política externa brasileira, na busca por soluções duradouras.

A atuação do Brasil como líder da MINUSTAH diz muito sobre a ação de sua política externa. De acordo com o ministro das Relações Exteriores da época, Celso Amorim, essa operação foi apenas um ato de coerência com os discursos de multilateralismo que o governo defendia. Porém, em uma análise mais ampla, essa liderança tem um significado muito maior que um mero ato de coerência. A liderança na MINUSTAH e o interesse e comprometimento do país com questões de direitos humanos em sua política externa, decorrem do anseio do governo pela liderança regional e o prestígio internacional e, mais importante, do desejo de obter um assento permanente no Conselho de Segurança da ONU.

Nesta perspectiva, por exemplo, Eliane Cantanhêde afirma que o Brasil se ofereceu para a posição a vista de se "acertar" com os Estados Unidos que há muito tempo queriam que o país se encarregasse da segurança das Américas abaixo do México (SILVA, 2004, p. 81). Ou seja, a liderança do Brasil em uma missão da ONU tão importante sugere não só a posição de líder regional, mas também a expectativa do apoio dos EUA nos fóruns internacionais. $O$ apoio internacional dos EUA é tão importante nesse contexto de política externa devido à sua posição dentro da ONU: é o país que mais detêm poder dentro da organização, além de comandar e sustentar as mais importantes missões ${ }^{6}$. Neste sentido, aumentar o prestígio brasileiro perante aos EUA seria uma estratégia relevante, muito vantajosa naquele momento para os interesses da política externa nacional.

Em vista disso, Lula, um ano após o inicio da MINUSTAH, repete a proposta à Assembleia Geral da ONU de promover a reforma para ampliar o número de membros permanentes no Conselho de Segurança (CERVO e BUENO, 2008, p. 505). Com base neste pedido, nota-se que:

\footnotetext{
${ }^{5}$ Disponivel em: <https://www.youtube.com/watch?v=LPI74TQ6Gy4> Acesso em 25/02/2016 às 14 h50.

${ }^{6}$ Disponível em: <https://almanaque.abril.com.br/planeta-onu/pdfs/politica-2013.pdf> Acesso em 25/02/2016 às $15 \mathrm{~h} 40$.
} 
"O tradicional desejo de formuladores de política do Brasil de fazer do País um ator relevante retorna com vigor. A busca pelo prestígio internacional por meio de um assento permanente no Conselho de Segurança e da mudança nos parâmetros de participação em forças de paz internacional podem ser as evidências mais fortes de uma turbulência no executar político brasileiro, seja em definir prioridades e objetivos, seja em formular estratégias que afetam positivamente outros atores."

Todo esse contexto mostra que a descoberta e a preferência pelo Brasil por parte dos haitianos se justificava na agenda da política externa brasileira e na proximidade que os haitianos tiveram com os brasileiros após o Jogo da Paz (CERVO, BUENO, 2008). Além disso, a presença do exército brasileiro no Haiti intensificou a relação de proximidade dos haitianos com os brasileiros, que em meio a este clima amistoso, presumiram que seriam muito bem acolhidos em uma possível migração ao país que agora liderava a nova missão da ONU.

A imigração foi relativamente alta para os padrões brasileiros, ao ponto que o CONARE (Comitê Nacional para Refugiados - ligado ao Ministério da Justiça) sentiu-se despreparado para atender tantas solicitações de refúgio, particularmente intensificadas após o ano de 2010. Estima-se que aproximadamente 6.000 haitianos deram entrada no Brasil logo após o terremoto, e de acordo com este mesmo órgão, grande parte deles solicitou a condição de refugiado (ZAFFARONI, 2012, p. 121). Segundo dados da pesquisa feita pelo Conselho Nacional de Imigração (CNIG) e Ministério do Trabalho $^{7}$ : a busca por emprego, o desejo de ajudar os parentes que ficaram no Haiti, a perda de tudo que tinham devido ao terremoto, a violência, a falta de segurança, e a conviç̧ão de que o Brasil estava aberto a imigrantes foram os principais motivos pelos quais os haitianos vieram para cá.

Paulo Sérgio de Almeida, presidente do CNIG, afirmou em entrevista para SILVA (2015, p.183) que o CNIG e o CONARE trabalharam juntos para receber os haitianos por meio de uma proteção complementar que foi oferecida pelo governo federal. Ele ressalta que desde 2010 foram apresentadas solicitações de refúgio de haitianos ao CONARE, e que foram unidos esforços para resolver esse fluxo migratório desde então.

O trajeto feito pelos imigrantes sem vistos geralmente se inicia na República Dominicana e segue para o Panamá por via aérea. Posteriormente por via fluvial ou terrestre, os haitianos passam pelo Peru ou Equador, e chegam à fronteira do Brasil-, Amazonas e Acre-, através da Bolívia e do Peru, sem grandes dificuldades, já que não thes são pedidos vistos nestes países. As fronteiras brasileiras mais frequentes são Tabatinga-, do estado de Amazonas-, Assis Brasil e Brasiléia-, ambos os municípios do Acre-, e alguns conseguiram chegar pela região Centro-Oeste, por Corumbá, estado de Mato Grosso do Sul, e o percurso pode durar de três a quatro meses.

O trajeto é escolhido de acordo com a facilidade que ele sugere, e foi verificada a atuação de "coiotes" nesse processo. Coiotes são pessoas contratadas para intermediar a imigração ilegal nas fronteiras, agindo como facilitadores. Segundo os dados da Agência Brasileira de Inteligência (ABIN),

\footnotetext{
${ }^{7}$ Disponível em <http://www.migrante.org.br/images/arquivos/pesquisacni-pucminas.pdf> Acesso em $25 / 02 / 2016$ às $10 \mathrm{~h} 00$
}

Revista do Direito [ISSN 1982-9957]. Santa Cruz do Sul, v. 3, n. 50, p. 98-117, set./dez. 2016. https://online.unisc.br/seer/index.php/direito/index 
a rede de coiotes que atua para trazer os haitianos para o Brasil já faturou cerca de US\$60 milhões desde $2010^{8}$.

A rede clandestina de imigração pode trazer a falsa ideia de ser um dos caminhos mais fáceis para se chegar ao Brasil, porém muitos haitianos relatam que foram mantidos em cárcere privado até que seus parentes mandassem o dinheiro cobrado pela quadrilha, havendo também relatos de estupro de mulheres durante esse trajeto ${ }^{9}$. É importante ressaltar que os coiotes não se responsabilizam pela segurança e bem estar dos imigrantes, e muitos morrem nesse processo.

Em junho de 2011, as Nações Unidas pediram que os países de destino dos haitianos mantivessem as fronteiras abertas e não os deportassem, haja vista que o país, ainda não recuperado do terremoto de 2010, não estaria em condições de garantir à sua população a proteção necessária, principalmente aos grupos que já eram vulneráveis antes mesmo do acidente. Nessa mesma linha, o ACNUR solicitou que os países emitissem um visto temporário de caráter humanitário aos haitianos, a fim de garantir a estadia deles até que seu país se estabilizasse ${ }^{10}$. Muito embora 0 visto não seja a medida mais pertinente e coerente com a legislação brasileira, ele tem evitado a imigração clandestina e todas suas implicações negativas.

Em conformidade ao apelo do ACNUR, o governo brasileiro emitiu uma resolução normativa (Resolução Normativa n.97 do CNIG) que concedia vistos aos nacionais do Haiti, em 2012, dois anos após o terremoto. Conforme Machado (2014), desde o ano de 2010, mais de 40 mil haitianos deram entrada no Brasil: pelo menos 28 mil entraram pelo estado Amazonas e 21 mil pelo Acre ${ }^{11}$. De acordo com o Ministério do Trabalho $^{12}$, 43.781 imigrantes haitianos ganharam o direito de solicitar residência permanente no país em novembro de 2015. E, ainda de acordo com o Ministério do Trabalho, já são 70 mil haitianos em território brasileiro ${ }^{13}$.

Apesar de o visto ter contribuído para que os haitianos fizessem um caminho seguro até o Brasil, percebeu-se o grau de improviso e medidas paliativas no que tange ao processo de inserção dos novos migrantes na sociedade brasileira, tal como acesso à alimentação, moradia e emprego. De fato, como migrantes e não como refugiados, a proteção oferecida pelo governo nacional seria ainda mais precária, contando com soluções temporárias e provisórias.

Dessa forma, os procedimentos de acolhimento ficaram por conta da Pastoral do Migrante e da Igreja Católica de Manaus, e não foi uma tarefa fácil à medida que a cada dia chegava centenas de haitianos. Por sorte, essas entidades contaram com ajuda de muitos voluntários que os encaminhavam para casas de acolhidas.

\footnotetext{
${ }^{8}$ Disponível em: <http://brasil.estadao.com.br/noticias/geral,rede-de-coiotes-ja-faturou-us-60-mi-comhaitianos-diz-relatorio,1692709> Acesso em 25/06/2015 às 13 h00.

${ }^{9}$ Disponível em: <http://brasil.estadao.com.br/noticias/geral,rede-de-coiotes-ja-faturou-us-60-mi-comhaitianos-diz-relatorio,1692709> Acesso em 25/06/2015 às $13 \mathrm{h00}$.

${ }^{10}$ Disponível em: <http://www.acnur.org/t3/portugues/noticias/noticia/onu-pede-que-governos-naodeportem-haitianos/>. Acesso em: 03 mar. 2014 às $15 \mathrm{~h} 00$.

${ }^{11}$ Disponível em: <http://www.altinomachado.com.br/2014/04/acre-exporta-imigrantes-haitianos-e-se.html>. Acesso em 23/01/2016 às $13 \mathrm{~h} 00$.

12 Disponível em: < http://portal.mte.gov.br/noticias-mte/1300-governo-brasileiro-garante-direitos-paraimigrantes-haitianos> Acesso em 25/02/2016 às $14 \mathrm{h00}$.

${ }^{13}$ Disponível em: <http://portal.mte.gov.br/noticias-mte/1300-governo-brasileiro-garante-direitos-paraimigrantes-haitianos> Acesso em 25/02/2016 às 14 h00.
}

Revista do Direito [ISSN 1982-9957]. Santa Cruz do Sul, v. 3, n. 50, p. 98-117, set./dez. 2016. https://online.unisc.br/seer/index.php/direito/index 
Em Manaus, os homens foram conseguindo emprego no setor terciário: construção civil, transporte e serviços, como mecânicos ou eletricistas, indústrias, supermercados, panificadores, fábricas de insumos e frigoríficos. Geralmente são áreas que uma grande parte de trabalhadores brasileiros não se interessa, devido aos baixos salários e ao trabalho pesado. Ainda assim, muitos empregadores pagavam muito pouco e atrasavam o pagamento, gerando certo descontentamento por parte dos haitianos.

Um migrante de Belo Horizonte relata sua experiência: "Carregar caminhões e esse tipo de serviço, eu nunca fiz no meu país, eu carrego até $50 \mathrm{~kg}$ pra jogar dentro do caminhão"14. Já as mulheres, eram geralmente chamadas para trabalhar como domésticas, e muitas foram atraídas pela oferta de residir nas casas das famílias manauenses. Com o aumento da chegada dessa população e a disseminação dessa imigração na mídia brasileira, empregadores de outros estados começaram a procurar os trabalhadores haitianos.

Os empregadores primeiramente entravam em contato com a Pastoral do Migrante e depois iam até a cidade para estabelecer contato com eles. Os principais destinos foram Paraná, Rio Grande do Sul, Minas Gerais e Santa Catarina (COSTA, 2012, p. 95). Muitos deles também procuraram São Paulo, conhecido como polo industrial, e ainda houve um fluxo em direção ao Amapá, ao Pará e também para a Guiana Francesa que oferecia uma opção pelo idioma em comum, o francês.

Dessa forma, a preocupação de uma grande parte de brasileiros de que os haitianos estariam concorrendo no trabalho e retirando emprego parece não ter fundamento na realidade. Em sua palestra no $17^{\circ}$ Congresso Brasileiro de Sociologia, o professor da Universidade Federal do Rio Grande do Sul, Karl Martin Monsma, chamou a atenção para isso e garantiu que os trabalhadores haitianos foram contratados em empregos que são rejeitados por uma grande parte de brasileiros ${ }^{15}$. No entanto, ainda há certo grau de resistência quanto aos haitianos empregados no país:

\begin{abstract}
"O povo brasileiro desempregado e que paga seus impostos e veem seus direitos banidos por uma população de imigrantes que estão roubando seus empregos. Já são mais de 6 mil haitianos no Brasil que receberam carteira de trabalho e visto de permanência e terão uma cota prevista de 100 haitianos por mês com direito a trazer toda sua famílias, todos terão o direito ao visto de permanência, acha pouco, está havendo uma evasão em massa para o Brasil. [...] O povo haitiano está em febre em busca de ilusões no Brasil, aqui não é nenhum paraíso, há moradores de rua, há misérias, há favelas e falta sim emprego para a classe trabalhadora brasileira. Olhar a miséria de outros povos e importá-la para o Brasil é no mínimo insana. [...] O Brasil já contribuiu com milhões de reais para reconstruir o Haiti, toda reconstrução requer mão de obra, porque não buscam reconstruir seu próprio país. O Brasil quer fazer média perante a opinião internacional para conseguir um assento na ONU e com isso o povo brasileiro tem que fazer concorrência com estrangeiros em seu próprio país." (TÉLÉMAQUE, 2012, p.71)
\end{abstract}

\footnotetext{
${ }^{14}$ Disponível em:

<http://acesso.mte.gov.br/data/files/8A7C816A4AC03DE1014AE84BF2956CB6/Pesquisa\%20do\%20Projeto\%20 \%E2\%80\%9CEstudos\%20sobre\%20a\%20Migra\%C3\%A7\%C3\%A3o\%20Haitiana\%20ao\%20Brasil\%20e\%20Di\%C3 \%A1logo\%20Bilateral\%E2\%80\%9D.pdf> Acesso em 27/02/2016 às 09h30.

${ }^{15}$ Disponível em: <http://www.dmtemdebate.com.br/os-haitianos-e-o-efeito-no-mercado-de-trabalhobrasileiro/> Acesso em 01/03/2016 às 14 h00.
} 
Apesar de concordarmos que o visto tenha sido uma forma de o governo brasileiro ser bem visto internacionalmente para conseguir um assento na ONU resolver provisoriamente o problema da imigração, entendemos que há desconformidade entre o processo decisório do CONARE e os instrumentos legais e convenções internacionais das quais o país é signatário. No próximo tópico veremos então em que medida a desconexão da decisão brasileira se torna estratégica para a política externa nacional.

\section{O PROCESSO DECISÓRIO DO CONARE E A MEDIDA COMPLEMENTAR DO CONSELHO NACIONAL DE IMIGRAÇÃO NO ÂMBITO DA POLÍTICA EXTERNA BRASILEIRA}

Levando em consideração a política externa brasileira como um dos fatores para analisar a migração haitiana, buscamos demonstrar o processo decisório do CONARE: como são tomadas suas decisões ao julgar quem é ou não refugiado no Brasil. O Comitê Nacional para Refugiados foi criado através da lei n.9.474/97, sendo o órgão responsável por analisar os pedidos de refúgio no país contando com seis membros do governo, um da sociedade civil e um da comunidade internacional.

O comitê é composto por representantes do Ministério da Justiça, das Relações Exteriores, do Trabalho, da Saúde, da Educação e do Desporto, além do Departamento da Polícia Federal (DPF), de uma organização não governamental comprometida com a causa dos refugiados (nos últimos anos a Cáritas Arquidiocesana do Rio de Janeiro e de São Paulo) e do próprio ACNUR (MOREIRA, 2010, p. 8).

As Cáritas são organizações não governamentais atreladas à Igreja Católica que atuam na defesa dos Direitos Humanos e tem papel histórico e relevante na acolhida dos refugiados no Brasil, além de também participarem do processo decisório quando da solicitação de refúgio por parte do imigrante.

O processo de acolhimento e integração dos refugiados no Brasil é feito pelo ACNUR, pela sociedade civil e pelo governo brasileiro (CONARE). Todos os membros do CONARE e a sociedade civil são mandatários do ACNUR, órgão da ONU responsável pela proteção dos refugiados na esfera internacional e, quem repassa para as instituições migratórias nacionais as orientações e a verba destinadas a essa prática de proteção. Os refugiados recebem toda a assistência dos órgãos que ficam responsáveis por proteger e integrá-los na sociedade brasileira, recebendo o auxílio financeiro do ACNUR e do CONARE. Além disso, as instituições migratórias se encarregam da integração local, da repatriação voluntária e do reassentamento dos indivíduos, que nas palavras de Moreira (2007, p. 2) são as soluções duráveis executadas para os refugiados (ainda que já defasadas).

A integração local é indispensável para que o refugiado possa reconstruir sua vida no país em que foi acolhido, contando com toda a assistência das instituições envolvidas. Os principais fatores iniciais de integração social são o aprendizado do idioma falado no país e a garantia de um emprego. E, posteriormente, tendo o refugiado se integrado à sociedade e se estabilizado no segundo país, este pode optar por retornar ao seu país de origem quando e se os motivos que causaram o deslocamento forçado deixam de existir, através da repatriação voluntária. E por fim temos o

Revista do Direito [ISSN 1982-9957]. Santa Cruz do Sul, v. 3, n. 50, p. 98-117, set./dez. 2016. https://online.unisc.br/seer/index.php/direito/index 
reassentamento, enquanto uma terceira alternativa ao refugiado ao qual o governo brasileiro tem grande comprometimento (Declaração do México, de 2004).

Moreira (2007, p.13) descreve a assistência prestada aos refugiados que abrangem direitos relacionados à saúde, alimentação e moradia. Segundo a autora, os solicitantes de refúgio e os refugiados têm acesso aos hospitais públicos, medicamentos custeados pelo ACNUR, e acompanhamento psicológico custeado por um repasse do governo ao CONARE. Além disso, o Serviço Social do Comércio (SESC) oferece atendimento gratuito odontológico. No tocante a alimentação, os solicitantes e refugiados recebem $60 \%$ de desconto no preço da refeição, através de um projeto realizado pelas Cáritas e o SESC, no caso do estado de São Paulo. As Cáritas também possui convênio com albergues para abrigar essa população, além das casas de abrigos mantidas pela Prefeitura Municipal e o Governo do Estado de São Paulo.

É a privação de alguns desses direitos, no caso dos haitianos, diante da posição do governo brasileiro de não reconhecê-los como refugiados, que podemos analisar com mais detalhes. Apesar de seus direitos humanos e liberdades terem sido violados largamente em seu país de origem, e do pedido por sobrevivência implícito na emigração, seus pedidos de refúgio foram indeferidos pelo CONARE, não considerando os aspectos abrangentes da Declaração de Cartagena, incorporada pela Lei $9.474 / 97$, no inciso III do artigo $1^{\circ}$, em outros termos, a ligação direta da violação de direitos humanos como causa do refúgio.

O Comitê entendeu que a expressão "fundados temores de perseguição", é o elemento fundamental da definição de refugiado conforme o Manual do ACNUR de Procedimentos e Critérios para Determinar a Condição de Refugiado (ACNUR, 1992, p. 12), e optou por entregar a responsabilidade nas mãos do CNIG que thes garantiu o visto solicitado pelo ACNUR, como medida complementar. A Resolução Normativa $N^{\circ} 97^{16}$ de 2012, consistia inicialmente em conceder 1.200 vistos permanentes por ano aos haitianos, que mais tarde foi aumentado devido à grande quantidade de haitianos entrando em solo brasileiro. O visto humanitário tem validade de cinco anos, podendo ser estendido por mais cinco. Segundo nota de esclarecimento do Ministério das Relações Exteriores, desde a Resolução Normativa em questão foram emitidos 16 mil vistos permanentes para haitianos pela embaixada do Brasil em Porto de Príncipe ${ }^{17}$.

O CNIG prorrogou essa resolução em 2013, e novamente no ano de 2015 , sendo que o novo prazo se iniciou no final de outubro ${ }^{18}$. A concessão de esta medida complementar foi uma forma do governo brasileiro manifestar mais uma vez sua participação ativa nos assuntos humanitários internacionais e ser bem visto pela comunidade de direito internacional e pela ONU, como aspectos da sua política externa desde o governo de Fernando Henrique Cardoso, e aprofundado nos governos de Luis Inácio Lula da Silva.

\footnotetext{
${ }^{16}$ Disponível em:

<http://portal.mte.gov.br/data/files/8A7C816A350AC8820135687F345B412D/RESOLU\%C3\%87\%C3\%830\%20N ORMATIVA\%20N\%C2\%BA\%2097.pdf>. Acesso em 12/10/2015 às 22h00.

${ }^{17}$ Disponível em: <www.itamaraty.gov.br/index.php?option=com_content\&view=article\&id=10438:nota-deesclarecimento-haiti\&catid=42\&lang=pt-BR\&ltemid=280>. Acesso em 10/11/2015 às 09h00.

${ }^{18}$ Disponível: <http://radioagencianacional.ebc.com.br/direitos-humanos/audio/2015-08/prorrogado-prazopara-concessao-de-visto-humanitario-aos-haitianos>. Acesso em 24/09/2015 às 17h00.
} 
Embora o visto confira aos haitianos um processo de entrada seguro e livre de coiotes, após entrarem em território brasileiro eles não obtêm qualquer ajuda do governo ou das autoridades migratórias, ficando tarefa das ONG's inseri-los nas sociedades e no mercado de trabalho. Para mais, outro inconveniente do visto é que a sua resolução normativa é vulnerável de suspensão, enquanto que um refugiado não pode ser devolvido ao país de origem que esteja ameaçando sua vida e liberdade, direito assegurado pelo princípio de non-refoulement (não devolução) contido no Estatuto dos Refugiados.

Para compreendermos melhor a escolha do processo decisório das entidades migratórias brasileiras em relação aos haitianos, vamos analisar as convenções e legislações das quais elas se valeram para essa tomada de decisão: a Convenção de Genebra, de 1951; a Declaração de Cartagena, de 1984; a Lei no 9.474, de 1997, o Estatuto dos Refugiados.

A Convenção de Genebra de 1951 foi uma Conferência de Plenipotenciários das Nações Unidas convocada para redigir um ordenamento que regulasse o status legal de refugiados. E então foi estabelecida a Convenção Relativa ao Estatuto do Refugiado ${ }^{19}$ de 1951 que definiu refugiado todo aquele que:

“(...) devido a fundados temores de ser perseguida por motivos de raça, religião, nacionalidade, por pertencer a determinado grupo social e por suas opiniões políticas, se encontre fora do país de sua nacionalidade e não possa ou, por causa dos ditos temores, não queira recorrer a proteção de tal país; ou que, carecendo de nacionalidade e estando, em consequência de tais acontecimentos, fora do país onde tivera sua residência habitual, não possa ou, por causa dos ditos temores, não queira a ele regressar."

É importante observar que essa convenção foi convocada em um período pós Segunda Guerra Mundial (há cerca de 60 anos) e por isso teve um caráter estritamente ligado à perseguição, seja ela de natureza religiosa, política, étnica, por raça entre outras. Entretanto, o caráter humanitário que a convenção pressupunha, ficou subentendido, limitando o espírito de amplo alcance que ela denotava, uma vez que sua interpretação fica de livre escolha para os signatários.

Essa discricionariedade dos Estados relativa ao regime proteção dos refugiados pôde ser bastante percebida no período pós Guerra Fria. Isso de deve por que após o término da disputa entre os dois blocos, embora ainda houvesse conflitos internos, o interesse dos Estados em ajudar e acolher os refugiados diminuiu. Moreira (2012, p. 177) afirma que essa nova conjuntura ocasionou uma crise no estatuto do refúgio à medida que a efetividade do regime internacional da ONU passou a ser bastante questionada.

A autora explica que nesse período pós Guerra Fria muitos imigrantes foram acusados de solicitar refúgio no intuito de regularizar sua situação no país de ingresso sem se adequarem à condição de refugiado e, por esse motivo os países começaram a adotar uma política migratória para refugiados mais restritiva, a fim de controlar essa imigração clandestina.

A Declaração de Cartagena de 1984 foi influenciada pela Convenção da Organização de Unidade Africana (OUA) que Rege os Aspectos Específicos dos Problemas dos Refugiados em África, de

\footnotetext{
${ }^{19}$ Promulgado pelo Decreto 50.215/61 Relativo ao Estatuto dos Refugiados.
} 
1969. Essa convenção africana foi elaborada a partir da preocupação do crescente e incessante número de refugiados no continente e se fundamenta na Convenção das Nações Unidas e na Declaração Universal dos Direitos Humanos, reconhecendo o direito do gozo da liberdade sem discriminação e dos direitos fundamentais.

Tomando como exemplo, a Declaração de Cartagena expôs a necessidade de ampliar o conceito de refugiado levando em consideração o que foi previsto na Convenção da OUA, e além dos elementos da Convenção de 1951 e do Protocolo de 1967, inclui na categoria de refúgio as pessoas que tenham fugido de seu país de origem:

"(...) por que a sua vida, segurança ou liberdade tenham sido ameaçadas pela violência generalizada, a agressão estrangeira, os conflitos internos, a violação maciça dos direitos humanos ou outras circunstâncias que tenham perturbado gravemente a ordem pública." (Declaração de Cartagena de 1984).

Consideramos estas normas e regras nacionais e internacionais enquanto um conjunto de normas jurídicas, mas também um "processo social" com incidência na realidade conforme Bull (2002, p. 148). O autor desconsidera o direito como apenas um "conjunto de normas" teóricas e abstratas, entendendo que o processo decisório também deve levar em consideração o contexto das esferas social, política e moral.

Além disso, o autor destaca que essas esferas exercem papel importante nas decisões legais. Dessa maneira, consideramos que a aplicação das normas jurídicas deve ser um processo decisório pautado na realidade social e política, afinal, elas são aplicadas em contextos reais que englobam também todo um conjunto de fatores externos que influenciam estas decisões, o que Bull (2002) chama de fatores "exógenos", afastando a análise das leis por meio de um plano puramente normativo e abstrato.

E foi neste sentido, que em 1997 o Brasil produziu uma lei que incorporava todo um conjunto de proteção internacional de refugiados que foi um marco para o avanço na política de refugiados brasileira, visto que também estava de acordo com o Programa Nacional de Direitos Humanos (PNDH), produzidos um ano antes (1996) e que previa a existência de uma lei para refugiados (SILVA, 2015, p.148-149). A lei regulamentou o status de refugiado aos indivíduos que foram obrigados a deixar seu país devido à grave e generalizada violação de direitos humanos, inspirado na Declaração de Cartagena:

"Será reconhecido como refugiado todo indivíduo que: I - devido a fundados temores de perseguição por motivos de raça, religião, nacionalidade, grupo social ou opiniões políticas encontre-se fora de seu país de nacionalidade e não possa ou não queira acolher-se à proteção de tal país; II - não tendo nacionalidade e estando fora do país onde antes teve sua residência habitual, não possa ou não queira regressar a ele, em função das circunstâncias descritas no inciso anterior; III - devido a grave e generalizada violação de direitos humanos, é obrigado a deixar seu país de nacionalidade para buscar refúgio em outro país." (Art. 1\%/lei nº 9.474 de 22 de Julho de 1997). 
Passados dezoito anos da Lei $n^{\circ}$ 9.474, o Brasil, signatário da mesma, lamentavelmente ainda segue os padrões restritivos estabelecidos pela Convenção de Genebra que faz 65 anos de aniversário este ano. O país é teoricamente um dos mais modernos em termos legislativos, com produção de leis extremamente elogiadas pelo ACNUR. Contudo, o governo brasileiro e as autoridades migratórias tendem a manter essa interpretação restritiva das leis, limitando, sobretudo, o refúgio ao fator "perseguição".

Ou seja, é necessário que o estrangeiro prove que está sendo de fato perseguido por outro indivíduo. Considerando isso, valemo-nos de BULL (2002, p.148) para trazer a discussão da necessidade de reconhecermos que os processos decisórios são processos sociais, e que as decisões devem ser moldadas com base no conjunto de regras legais postas e também nos chamados fatores "exógenos" dos quais citamos.

Entendendo assim, Anselmo Henrique, Procurador da República no Acre entrou com ação judicial contra o governo para que os haitianos tivessem direito ao status de "refugiado". Anselmo explica em Ação Civil Pública ${ }^{20}$ que na época em que o Estatuto dos Refugiados foi criado não era muito comum que as pessoas migrassem devido às catástrofes naturais, que esta é uma preocupação atual que se somada a fatores sociais, econômicos e políticos geram a necessidade de migração. É o que ele chamaria de catástrofes socioambientais e o que denominamos como migrações internacionais mistas (SILVA, 2015, p. 175).

Silva $(2015$, p.17) se refere justamente às essas migrações que são impulsionadas pela combinação da violência generalizada ou perseguição, com fatores econômicos, sociais e culturais. Nessa mesma linha Long (2013, p. 8) defende que a perseguição e a pobreza são interconectadas, e frisa que essa emigração é comum nos Estados em que a crise de governo leva o país a um longo e profundo estado de subdesenvolvimento, não podendo mais garantir a sua população os serviços básicos. E chama atenção para a importância de reconhecer quando os simples migrantes internacionais passam a ser refugiados. Isso porque quem busca refúgio em qualquer circunstância, também busca emprego e novas oportunidades econômicas para garantir sua sobrevivência, por isso a importância de uma análise mais aprofundada nas causas da migração, para diferenciar claramente os refugiados políticos dos migrantes econômicos.

Neste contexto de migrações internacionais mistas é que podem ser enquadrados os haitianos. O Estado que não pode Ihes assegurar seus direitos fundamentais, oferecer serviços básicos e garantir a segurança e de sua população, está violando diretamente seus direitos humanos. Acreditamos que os fatores de perseguição são inúmeros e vão sofrendo mudanças com o decorrer do tempo.

Não é possível prever o que virá a ameaçar a segurança de um indivíduo, e por isso a necessidade de um maior entendimento sobre o que seria "perseguição" em si, para garantir a mais ampla proteção a esses imigrantes que se sentem ameaçados, e que cada vez mais essa ameaça não parte de um indivíduo específico, mas de fatores combinados. Nessa mesma linha, Derderian e Schockaert (2009, p. 107) dizem ser essencial às agências humanitárias reconsiderar mudanças nas respostas

\footnotetext{
${ }^{20}$ Disponível em: <file:///C:/Users/Asus/Downloads/acp.refugiados.haiti.pdf> Acesso em 04/08/2013 às 14h00
} 
governamentais aos novos movimentos populacionais para dar assistência às pessoas que estão fugindo da violência.

Embora o governo do Brasil incline-se por essa interpretação restritiva da legislação, essa ampliação tem sido muito discutida pelos atores políticos internacionais envolvidos no tema, tendo em vista as mudanças internacionais, além dos valores protegidos por esta convenção. O tema foi recentemente debatido no evento "Cartagena + 30", ocorrido em Brasília em dezembro de 2014, e ali elaborado o Plano de Ação do Brasil, nos quais está fixado o compromisso do país em trabalhar para defender e apoiar os mais altos padrões de proteção regional e internacional. E, juntamente a isso, adotar soluções inovadoras para proteger os refugiados ${ }^{21}$.

Apesar dessa recente preocupação dos envolvidos na formulação do Plano de Ação, é no mínimo paradoxal que o governo brasileiro que se mostrou por muitas vezes tão moderno juridicamente incluindo os principais princípios de direito internacional em suas legislações e envolvido com questões humanitárias em sua política externa, tenha restringido de tal maneira o alcance da proteção das suas leis no caso dos haitianos.

Prova disto foi o posicionamento brasileiro diante do fluxo de angolanos que fugiam de uma guerra civil em 1992. O governo concedeu-lhes primeiramente o visto de turista para que eles pudessem ingressar no país em segurança. $\mathrm{E}$, considerando que os vistos expirariam dentro de três meses, o que colocaria esses imigrantes em uma situação de desamparo, o governo decidiu então enquadrá-los no regime amplo de refugiado da Declaração de Cartagena de 1984 (MOREIRA, 2012, p. 179).

Outro acontecimento que nos chama atenção a respeito da causa dos refugiados como política externa do Brasil foi a colaboração do país no reassentamento de afegãos, em 2001, e palestinos, em 2007 (SILVA, 2015, p. 256). Promovendo doações às instituições internacionais e às agências da ONU para refugiados, além dos custos voltados para a assistência e inserção desses indivíduos em território brasileiro. A decisão foi proferida no dia 20 de junho, o Dia Mundial do Refugiado, evidenciando a intenção do país de destacar sua política externa voltada para a causa, ganhando notoriedade na comunidade internacional no "uso estratégico do reassentamento" (SILVA, 2015, p. 255).

O empenho brasileiro na causa dos palestinos mostra o comprometimento com os princípios da convenção internacional e com sua própria legislação, e o desejo de ser reconhecido como um país humanitário com avançadas normas de refúgio (SILVA, 2015, p. 267). Ou seja, o Brasil já havia adotado uma interpretação mais ampla do conceito de refugiado para a proteção dos nacionais de Angola à época, e se propôs a colaborar com as mais amplas causas de refúgio; por isso é fundamental analisar os precedentes que levaram o país a tomar essa posição negativa em relação ao imigrante haitiano.

Se por um lado, a MINUSTAH e o visto humanitário concedido aos haitianos colocam o Brasil em uma posição favorável perante a ONU e toda a comunidade internacional, entendemos que essa negação tenha sido uma maneira estratégica de se poupar de um constrangimento internacional,

\footnotetext{
${ }^{21}$ Disponível em: < http://www.acnur.org/t3/portugues/noticias/noticia/cartagena-30-paises-da-americalatina-e-o-caribe-adotam-plano-de-acao-comum/>. Acesso em 20/02/2016 às 18 h00.
} 
enquanto um fator exógeno, na acepção proposta por Bull (2002). Afinal, o país lidera uma Missão de Paz das Nações Unidas para estabilizar o Haiti há mais de dez anos e, ainda assim os haitianos continuam emigrando de forma geral, sobretudo para buscar segurança e estabilidade em outras partes do mundo.

É possível visualizar o embaraço que o país passaria caso concedesse o status de refúgio aos haitianos: seria assumir internacionalmente que sua missão não obteve sucesso. E esse atestado de fracasso não é muito conveniente para o governo e sua política externa atual que almeja veementemente o assento permanente no Conselho de Segurança das Nações Unidas, além de maior visibilidade regional e internacional.

Somados a isso, outro mal-estar que o país parece tentar evitar é revelar sua falta de estrutura migratória em receber tamanha quantidade de refugiados de uma vez só. Ventura e Illes (2012), em matéria para o "Le Monde Diplomatique Brasil" ${ }^{22}$, destacam que há deficiências no atendimento aos estrangeiros e que o país não dispõe de um serviço próprio de imigração.

Os autores explicam que um dos motivos é a falta de formação e preparo dos profissionais do Departamento de Polícia Federal que fazem o primeiro contato com os imigrantes. Esses profissionais tendem a ter uma interpretação restritiva da condição de refúgio e solicitam documentos que os imigrantes sequer sabem como conseguir, tornando desconfortável o primeiro contato dos imigrantes com as autoridades brasileiras.

A estudante Laurette Dernadinil em entrevista para o portal "O estrangeiro" reclama que o processo para regularizar sua situação aqui no Brasil é muito burocrático: "É preciso apresentar vários documentos e o processo é demorado e complexo. Tenho o visto de permanência, mas foi difícil conseguir"23.

Nessa linha, Gonzalez e Silva (2015, p. 58) afirmam existir uma defasagem entre o discurso oficial e a ação do governo brasileiro. Afinal, o Brasil acolhe em um ano o que a Itália acolhe em uma semana, havendo uma grande disparidade na prática de acolhimento a refugiados, se considerada a extensão territorial dos dois países. Em vista disso, os autores alegam que o país tem apenas uma participação simbólica nos movimentos migratórios mundiais, contribuindo financeiramente com organizações internacionais, mas mantendo uma política doméstica insuficiente.

Apesar de já termos tido no passado um bom exemplo de acolhimento aos refugiados apoiado nos parâmetros da Declaração de Cartagena (como no caso dos angolanos), fica claro que há uma contradição entre o discurso e a prática do governo brasileiro, percebida no caso dos haitianos. Ou seja, os processos decisórios do CONARE não apresentam uma linha sólida de silogismo, ora considerando os fatores exógenos, ora não. O que nos faz crer que o governo toma suas decisões a respeito de refugiados com base no que é conveniente para sua imagem internacional diante da comunidade internacional, pelo menos no caso dos haitianos.

Diante disso, obviamente que é muito improvável que todos os haitianos presentes no país sejam refugiados propriamente ditos, é muito improvável que todos o sejam. Porém, o problema da via complementar de proteção é a impossibilidade da solicitação de refúgio no país. E no que

\footnotetext{
${ }^{22}$ Disponível em: < http://www.diplomatique.org.br/artigo.php?id=1121> Acesso em 12/03/2016 às $11 \mathrm{~h} 20$.

${ }^{23}$ Disponível em: < http://oestrangeiro.org/2012/07/16/haitianos-historias-diversas-e-um-mesmo-destino/> Acesso em 15/03/2016 às 10h16.
} 
concerne à lei do refúgio, garante-se que todos os estrangeiros têm o direito de solicitar o reconhecimento da condição de refugiado a qualquer autoridade migratória (SILVA, FERNANDES E SEVERO; 2015; p. 93). Por esse motivo, entendemos que o CONARE deveria ao menos assegurar aos haitianos que chegam ao Brasil o direito de serem ouvidos e terem seus pedidos de refúgio analisados caso a caso conforme a própria legislação.

O processo decisório de refúgio se inicia nas autoridades migratórias da Polícia Federal que o encaminha o solicitante para o CONARE. Ali são feitas entrevistas e são analisadas as condições de vida do solicitante em seu país de origem, e enquanto corre o processo de decisão, são emitidos documentos de identificação provisória pela autoridade migratória e carteiras de trabalho provisórias pelo Ministério do Trabalho.

Silva, Fernandez e Severo (2015) ressaltam que a "proteção subsidiária" (aqui nos referimos como proteção complementar) indica que primeiramente deve-se analisar a solicitação de refúgio, e que somente no caso de o solicitante não ser elegível é que se deve recorrer à "subsidiária".

No entanto, o CONARE vem adotando o encaminhamento direto das solicitações diretamente ao CNIg, isto é, a resolução tomada pelo governo brasileiro está lhes privando de um direito que é deles: "o direito a ter direito", na expressão de Arendt (1989).

Nesse sentido, Arendt associa os direitos humanos à noção de cidadania e ao princípio do "direito a ter direitos", e quando são negados ao homem, afetam-lhe substantivamente a condição humana (ARENDT,1989). Ademais, o direito de submeter um pedido de asilo e de ser considerado também está garantido no princípio de non-refoulement (DERDERIAN e SCHOCKAERT, 2009, p. 112), ou seja, os haitianos estão sendo privados do direito de ser refugiado, ou pelo menos do seu caso específico ser examinado.

A discricionariedade do Estado na interpretação de suas leis no tocante à concessão de proteção complementar por vezes a torna ineficaz. O haitiano não se vê amparado quando chega ao Brasil e há muitas barreiras na integração dessa população em nossa sociedade, principalmente por que esta depende da boa vontade das ONG's e da sociedade civil organizada.

Silva, Fernandez e Severo (2015, p. 99), citam que as medidas de proteção que foram adotadas pelo governo são insuficientes para a inserção dos haitianos no espaço público e para o reconhecimento como sujeitos de direitos. Além disso, Derderian e Schockaert (2009, p. 111) apontam que essa interpretação restritiva do direito dos refugiados faz com que os potenciais solicitantes de refúgio fiquem em uma espécie de "limbo jurídico" e com constante medo de serem deportados.

Por isso a discussão acerca do processo decisório do CONARE se faz tão importante neste contexto. A decisão do governo brasileiro foi claramente influenciada pelos objetivos de sua política externa, adotando uma posição estratégica para evitar o embaraço internacional. Embora os haitianos não estejam totalmente desamparados pelo visto humanitário há a necessidade de mostrar até que ponto o Brasil está agindo em conformidade com o seu comprometimento com temas humanitários e principalmente com a causa dos refugiados, e como isso afeta diretamente os direitos dos haitianos, assegurados pela própria lei brasileira.

Revista do Direito [ISSN 1982-9957]. Santa Cruz do Sul, v. 3, n. 50, p. 98-117, set./dez. 2016. https://online.unisc.br/seer/index.php/direito/index 
E, portanto, nos parece que não há uma consonância entre a política doméstica e a política externa do Brasil no que tange ao reconhecimento dos haitianos enquanto refugiados.

\section{CONSIDERAÇÕES FINAIS}

Levando em consideração todo o histórico político, social e ambiental do Haiti, percebemos que há raízes muito mais profundas nos fluxos emigratórios dos haitianos que deveriam ser levadas em consideração no processo decisório do CONARE, o que ao longo do texto nos referimos como fatores exógenos.

Apesar da tentativa da MINUSTAH de estabilizar o país há mais de dez anos, percebe-se que o país ainda tem um longo caminho a percorrer para que possa ser um país seguro para os haitianos. O Estado já não era capaz de garantir os direitos fundamentais básicos da população antes mesmo dos desastres ambientais, e após os terremotos, a situação se agravou ao ponto que os direitos humanos já não eram mais assegurados, levando os haitianos a deixarem seu país em busca de sobrevivência.

Por isso é necessário que o Brasil, como destino dessa população, amplie o alcance de suas próprias leis, como já feito antes, para que os haitianos gozem de todos seus direitos como refugiados, tendo maior assistência no tocante à inserção na sociedade brasileira e estabilidade no país. Apesar do comprometimento do Brasil com os mais altos padrões de proteção internacional aos refugiados, adotando e criando modernas legislações, é compreensível que o país não queira passar por esse embaraço internacional de reconhecer o fracasso de sua missão internacional e as lacunas e deficiências da sua política migratória para refugiados.

Dito isto, entendemos que a ONU e o Brasil precisam repensar a MINUSTAH como única forma de estabilizar o Haiti, já que não vêm surtindo os resultados desejados em torno da recuperação do país. O esforço para estabilizar o Haiti deve ser responsabilidade geral, de toda a comunidade internacional compartilhada e não apenas através de uma única missão liderada pelo Brasil. Apesar do país desejar e exercer certa liderança regional, nós percebemos um determinado padrão de insucesso na política adotada para estabilizar o Haiti, na medida em que os haitianos continuam a emigrar.

O governo brasileiro precisa agir em conformidade com as diretrizes de sua política externa no caso dos haitianos. Se por um lado temos esse exemplo de prática no caso dos imigrantes angolanos; por outro lado, os haitianos estão sendo mantidos às margens do pleno exercício de seus direitos, o que evidencia um processo decisório do CONARE marcado por fatores exógenos.

Entendemos também, que o Brasil parece não estar preparado para receber tamanha quantidade de refugiados de uma vez só, entretanto, o problema é real e os imigrantes continuam a entrar no país. Dessa maneira, deve haver uma reestruturação nas entidades migratórias brasileiras para melhor atender essa população. O problema dos refugiados não deve ficar somente nas mãos da sociedade civil organizada do Brasil, é responsabilidade também do governo de garantir os direitos fundamentais desses imigrantes.

Revista do Direito [ISSN 1982-9957]. Santa Cruz do Sul, v. 3, n. 50, p. 98-117, set./dez. 2016. https://online.unisc.br/seer/index.php/direito/index 
Sabe-se que o CONARE conta com poucos funcionários para analisar os pedidos de refúgio, por isso seria quase impossível atender a todas as solicitações dos haitianos, dessa maneira, necessita-se de uma ampliação no quadro dos empregados, para que todas as solicitações sejam atendidas conforme garante a lei. Além disso, o CONARE precisa adotar um processo decisório sólido para atender aos solicitantes de refúgio, e não agir conforme o conveniente, como ficou claro no caso dos haitianos.

Outra entidade que parece necessitar de melhorias é o Departamento da Polícia Federal, que normalmente faz o primeiro contato com os imigrantes. Os agentes policiais precisam estar devidamente qualificados e preparados para lidar com essa população. Isso por que os imigrantes passam por muitas dificuldades durante a viagem de travessia para chegar ao destino final, chegando cansados e com medo, conquanto o primeiro contato com a polícia deve ser pacífico e acolhedor.

A crise global dos refugiados existe e os fluxos imigratórios são cada vez mais frequentes em todo o mundo. Diante dessa crise, o Brasil pode ser escolha de outros imigrantes, espalhados pelo planeta inteiro. Por isso, o país precisa estar bem preparado para receber esses indivíduos, e adotar um processo decisório sólido e plausível a fim de atendê-los em conformidade com a lei brasileira para refugiados.

Ou seja, julgamos necessário que o governo brasileiro volte sua política externa para a busca de valores humanitários que alega ter, e atue mais incisivamente na proteção refugiados no país, a começar pela concessão e reconhecimento dos haitianos, enquanto refugiados.

\section{REFERÊNCIAS}

AÇÃO CIVIL PÚBLICA. Anselmo Henrique Cordeiro Lopes. Ministério Público Federall

Procuradoria da República no Acre. 25 jan. 2012. Disponível em <file:///C:/Users/Asus/Downloads/acp.refugiados.haiti.pdf>. Acesso em 04/08/2013 às 14h00.

ACNUR. Manual de Procedimentos e Critérios para a Determinação da Condição de Refugiado - de acordo com a Convenção de 1951 e o Protocolo de 1967 Relativos ao Estatuto dos Refugiados. Brasília: ACNUR/CONARE, 1992.

ACNUR. Cartagena+30: países da América Latina e o Caribe adotam Plano de Ação em comum. ACNUR, Agência da ONU para refugiados. 03 dez. 2014. Disponível em: < http://www.acnur.org/t3/portugues/noticias/noticia/cartagena-30-paises-da-america-latina-e-o-caribeadotam-plano-de-acao-comum/>. Acesso em 20/02/2016 às 18h00.

ACNUR. ONU pede que governos não deportem haitianos. ACNUR, Agência da ONU para refugiados. 30 jun.2011. Disponível em:< http://www.acnur.org/t3/portugues/noticias/noticia/onupede-que-governos-nao-deportem-haitianos/> Acesso em: 03 mar. 2014 às $15 \mathrm{~h} 00$.

ACNUR. Declaração e Plano de Ação do México para Fortalecer e Proteção Internacional dos Refugiados na América Latina. ACNUR, Agência da ONU para refugiados. 2004. Disponível em: < http://www.acnur.org/t3/fileadmin/Documentos/portugues/BD_Legal/Instrumentos_Internacionais/Decl aracao_e_Plano_de_Acao_do_Mexico.pdf?view=1> Acesso em 25/02/2016 às 15 h00 e às 16 h00.

ANDRADE, José H. Fischel; MARCOLINI, Adriana. A política de proteção e de reassentamento de refugiados - breves comentários sobre suas principais características. Revista Brasileira de Política Internacional. Vol. 45 n 1: Brasília, 2002. 
ARENDT, Hannah. Origens do Totalitarismo. Tradução de Roberto Raposo. São Paulo: Companhia das Letras, 1989.

BRASIL. Lei 9.474 de 22 de julho de 1997. Define Mecanismos para Implementação do Estatuto dos Refugiados de 1951 e determina outras providências.

BULL, Hedley. A sociedade anárquica. Um estudo da ordem na política mundial/ Hedley Bull, prefácio por Williams Gonçalves. São Paulo: Editora Universidade de Brasília, 2002.

CAFFEU, Ana Paula; CUTTI, Dirceu. Só viajar! Haitianos em São Paulo: Um primeiro e vago olhar. Travessia: revista do migrante. N070 - Janeiro - Junho/2012.

CÂMARA, Irene Pessôa de Lima. Em nome da democracia. A OEA e a crise haitiana - 1991 - 1994 / Irene Pessôa de Lima Câmara. Brasília: Instituto Rio Branco; Fundação Alexandre de Gusmão; Centro de Estudos Estratégicos, 1998.

CERVO, Amado Luiz; BUENO, Clodoaldo. História da Política Exterior do Brasil. $3^{a}$ Ed. Brasília: UNB, 2008.

COSTA, Gelmino A. Imigração haitiana em Manaus: Presença da Pastoral do Migrante (relato). Travessia: revista do migrante. N68 - Janeiro - Junho/2011.

Haitianos em Manaus: Dois anos de imigração - e agora!. Travessia: revista do migrante. N070 - Janeiro - Junho/2012.

DECLARAÇÃO UNIVERSAL DOS DIREITOS HUMANOS. Unic/Rio/005. Jan. 2009. Disponível em <http://www.dudh.org.br/wp-content/uploads/2014/12/dudh.pdf> Acesso em 09/09/2014 ÀS 15 h00.

DERDERIAN, Katherine; SHOCKAERT, Liesbeth. Respostas a fluxos migratórios mistos: Uma perspectiva humanitária. SUR. Revista internacional de direitos humanos. Ano 6 - No10 - São Paulo - Junho/2009.

ESTADÃO. Rede de 'coiotes' já faturou US\$ $60 \mathrm{mi}$ com haitianos, diz relatório. Jornal o Estado de S. Paulo, 23 mai. 2015. Disponível em: < http://brasil.estadao.com.br/noticias/geral,rede-de-coiotes-jafaturou-us-60-mi-com-haitianos-diz-relatorio,1692709>. Acesso em 25/06/2015 às 13 h00.

FUNAG. Discursos selecionados do presidente Fernando Henrique Cardoso. FUNAG. 2009. Disponível em:< http://www.funag.gov.br/biblioteca/dmdocuments/Discursos_fhc.pdf> Acesso em $15 / 02 / 2016$ às $19 \mathrm{ho0}$.

GONZALEZ, Rodrigo Stumpf; SILVA, Cesar Augusto S. Os "boat people" do século XXI e a atual política externa brasileira para refugiados. Monções: Revista de Relações Internacionais da UFGD - Dourados, 2015.

ITAMARATY. Nota de Esclarecimento. Ministério das Relações Exteriores. 7 jul. 2015. Disponível em: < www.itamaraty.gov.br/index.php?option=com_content\&view=article\&id=10438:nota-deesclarecimento-haiti\&catid=42\&lang=pt-BR\&Itemid=280>. Acesso em 10/11/2015 às 09h00.

LONG, Katy. When Refugees Stopped Being Migrants: Movement, Labour and Humanitarian Protection. Migration Studies, v. 1, v.1, 2013.

MAJISTASCIC, Vanessa Braga. Haiti: segurança ou desenvolvimento no início dos anos 1990/ Vanessa Braga Majistatic. Curitiba: Appris, 2014. 42

MINISTÉRIO TRABALHO E EMPREGO. Projeto "Estudos sobre a migração haitiana ao Brasil e diálogo bilateral. $\quad$ MTE, $2014 . \quad$ Disponível: <http://acesso.mte.gov.br/data/files/8A7C816A4AC03DE1014AE84BF2956CB6/Pesquisa\%20do\%20 Projeto\%20\%E2\%80\%9CEstudos\%20sobre\%20a\%20Migra\%C3\%A7\%C3\%A3o\%20Haitiana\%20ao \%20Brasil\%20e\%20Di\%C3\%A1logo\%20Bilateral\%E2\%80\%9D.pdf> Acesso em 27/02/2016 às $09 h 30$. 
MINISTÉRIO DO TRABALHO E PREVIDÊNCIA SOCIAL. Governo brasileiro garante direitos para imigrantes haitianos. MTPS. Disponível em:<http://portal.mte.gov.br/noticias-mte/1300-governobrasileiro-garante-direitos-para-imigrantes-haitianos>. Acesso em 25/02/2016 às 14h00.

MOREIRA, Julia Bertino. Política em relação aos refugiados no Brasil (1947-2010). Tese de Doutorado em Ciência Política. Campinas, SP: Unicamp, 2012.

. O acolhimento dos refugiados no Brasil: políticas, frentes de atuação e atores envolvidos. Campinas, SP: 2007.

PINHEIRO, Letícia; MILANI, Carlos R. S. Política Externa Brasileira: As Práticas da Política e a Política das Práticas. Rio de Janeiro: Editora da Fundação Getúlio Vargas, 2012.

SANTIAGO, Adriana. Haiti por si. A reconquista da independência roubada/ Adriana Santiago (organizadora). Fortaleza: Expressão Gráfica e Editora, 2013.

SILVA, Carlos Eduardo Lins. Futebol, paz e riscos para o Brasil no Haiti. Política Externa. Vol.13 No 2 Setembro/ Outubro/ Novembro 2004.

SILVA, César Augusto S. A política migratória brasileira para refugiados (1998-2014). Curitiba: Íthala, 2015.

SILVA, Allyne Andrade; FERNANDES, Guilherme Antonio de Almeida Lopes; SEVERO, Thais Lara Marcozo. A proteção jurídica do imigrante indocumentado à luz dos direitos humanos: o reconhecimento do imigrante como sujeito de direito e o caso dos haitianos no Brasil. In: ALMEIDA, Guilherme Assis; PRADO, Alessandro Martis; SEVERO, Thais Lara Marcozo. Constituição do sujeito de direito e direitos humanos. Editora CRVI Editora UEMS. Curitiba/Dourados, 2015.

SIMÕES, Antônio José Ferreira. Brasil e Haiti: parceria em busca de um futuro melhor/ Cap. 2: III Seminário Brasil-Noruega sobre paz e reconciliação. Brasília: Ministério das Relações Exteriores; Fundação Alexandre de Gusmão,2011.

TÉLÉMAQUE, Jenny. Imigração haitiana na mídia brasileira: entre fatos e representações/ Jenny Télémaque. Rio de Janeiro: UFRJ/ECO, 2012.

VALLER FILHO, Wladimir. O Brasil e a crise haitiana: a cooperação técnica como instrumento de solidariedade e de ação diplomática. Brasília: FUNAG, 2007.

VENTURA, Deisy; ILLES, Paulo. Qual a política migratória do Brasil? DIPLOMATIQUE, 07 mar. 2011. Disponível em: < http://www.diplomatique.org.br/artigo.php?id=1121> Acesso em 12/03/2016 às $11 \mathrm{~h} 20$.

YOUTUBE. Brasil $X$ Haiti - Jogo da Paz. 23 set. 2006. Disponível em: <https://www.youtube.com/watch?v=LPI74TQ6Gy4>. Acesso em 25/02/2016 às 14h50.

ZAFFARONI, Eugenio Raúl. Derechos humanos: reflexiones desde el Sur/ Eugenio Raúl Zaffaroni y Susana Albanese; coordinado por Sebastián Alejandro Rey y Marcos Filardi. - $1^{\mathrm{a}}$ ed. - Buenos Aires: Infojus, 2012.

ZOLBERG, Aristide R.; SURHKE, Astri; AGUAYO, Sergio. Escape from violence. Conflict and the refugee crisis in the developing world/ Aristide R. Zolberg, Astri Suhrke, Sergio Aguayo . New York, Oxford: Oxford University Press, 1989.

\section{COMO CITAR ESSE DOCUMENTO:}

SILVA, Cesar Augusto; MORAES, Thays Mello. A Política Migratória Brasileira para Refugiados e a Imigração Haitiana. Revista do Direito, Santa Cruz do Sul, v. 3, n. 50, p. 98-117, set. 2016. ISSN 19829957. Disponível em: <https://online.unisc.br/seer/index.php/direito/article/view/7890>. Acesso em: doi:http://dx.doi.org/10.17058/rdunisc.v3i50.7890. 